\title{
Fostering Inclusive Capitalism for Spurring Entrepreneurship and Sustainable Growth: An Indian Perspective
}

\author{
Ms Raka Lahiry (Banerji) ${ }^{1,}$ Dr. Sudipti Banerjea ${ }^{2}$ \\ ${ }^{I}$ Asst. Prof. (Economics) Army Institute of Management Judges Court Road, Opposite Alipore Telephone \\ Exchange Kolkata. \\ ${ }^{2}$ Professor, Department of Commerce University of Calcutta College Street Campus Kolkata
}

\section{Introduction of the theme of the study:}

Entrepreneurship lies at the core of the process of economic development. Entrepreneurial motivation, in India, is present in a dormant way, which is palpable when we observe the petty "tea - stalls" doing enormous business across the villages of India, selling 'tit-bits' with tea. However, we find that their entrepreneurial capacities are severely constrained due to the absence of proper institutional mechanism of transforming unproductive wealth into capital. In the absence of a conducive entrepreneurial eco-system, these micro businesses fail to grow and reap the benefits of scale and scope economies. Typically, people can be found, living in shanty towns, functioning as street vendors and doing family based businesses that do not generate taxes, (Soto, 2001). Thus, though India is teeming with street entrepreneurs, hawkers and vendors, using their skills, frugal innovations, and physical assets to provide a wide variety of goods and services, which are capable of capturing the interest of the consumers, but, this is only an evidence to affirm the existence of a vast underground economy (Daodu, 2001), also known as 'the informal-sector', running parallel to the main one.

The informal sector thrives as the unregistered nursery of entrepreneurship while its business mortality rate is very high due to the lack of access to easy and affordable financial services. Thus, the fate of millions of potential entrepreneurs is trapped in a vicious circle of exclusion. It is not unnatural to believe that if this enterprising energy is provided with appropriate means to flourish then it can become the most important driver of a virtuous cycle of prosperity and economic growth that is sustainable, holistic, equitable and thus, meaningful in nature. Financial inclusion attempts to do this by improving the access of low-income and selfemployed people to loans and deposits, thus reducing their vulnerability and inducing some of them to formalise their businesses by bringing them into the mainstream economy. As 70\% of Indian population lives in villages, offering values that businesses crave for and a giant democratic country like ours has a large voter bank in rural India, therefore, there has to be a great future for "Inclusive Capitalism". Inclusive capitalism is such that it can be harnessed for creating structures of equal opportunities. To remain sustainable, it employs the frugal and inclusive principle like "more for less for more", (Prahalad and Krishnan, 2008), which means that it must deliver more value using less money and resources for more citizens. Thus, by extending the reach and scope of formal and organized financial systems, even the petty and marginalized enterprises, with low income, can be included in the virtuous cycle of wealth creation and, through graduated credit support, those can be lifted from lower sustenance levels to upper levels. In this way, financial inclusion of the micro and small enterprises offers scope to 'cultivate entrepreneurship' and induces them in this resource-constrained sector to formalise their businesses, adopt appropriate technology or upgrade their technology and improve the entrepreneurial ecosystem (Venkataraman,2004) by fostering innovation and macroeconomic resilience for attaining economic growth that is more holistic and sustainable in nature.

As India is gradually structurally transforming itself from a pre-dominantly agricultural country, it is inevitably growing more dependent to industries and services sectors. However, in its transition, as India reduced its dependence on agriculture from 50\% of GDP in 1950s to $18 \%$ in 2007 (GOI, 2008), 60\% of its population is still dependent on agriculture. Thus, the urgent need of creating opportunity for employment of its massive unemployed young labour force has to be created and thus India cannot afford to surpass manufacturing sector in its growth transition as it has the potential to create phenomenal employment opportunities. This is where the MSME sector can play a significant role in creating non-farm employment opportunities.

\section{Literature review:}

Capital investment is crucial to any productive activity which is possible only when adequate finance is available. There is a general belief that financial intermediation spurs the rate of investment through the dynamic routes of entrepreneurship in any economy. The endogenous growth literature emphasises the importance of availability of easy financial services for economic growth as they act lubricants in gearing up the entire productive capacity of the country by mobilising and channelizing the scarce resources to their most optimal and productive use. This is the reason that the nations and communities which actively promoted 
entrepreneurship development, demonstrated much higher levels of development than the nations whose institutions, policies and culture hindered entrepreneurship, (Landes, 1998). Economic development is achieved largely through productivity growth and this proposition has been empirically tested for the developing countries and found true (Schumpeter, 1949). Innovation has been identified as an engine of growth (King and Levine, 1993) which accords with the Schumpeter's view of productivity-led economic growth. The idea that finance-led economic growth can be safely ignored has been completely rejected. The early local experiments with liberalization in the mid-1970s and formation of strong financial infrastructure base generated a burst of rural entrepreneurialism that ignited the entrepreneurial motivation especially among the micro and small entrepreneurs in China and resulted in the spectacular 'Chinese Miracle' in the 1980s ( Studwell, 2002). Such conditions determine a country's capability to encourage the start-ups and influence the entrepreneurial process at the "bottom of the pyramid"( Prahalad, 2005).The proposition, that easy financial access generates economic growth, was also found true in roughly $85 \%$ of 71 developing countries during the period of 1960-1980 (Odedokun, 1996). Time Series Regression Analysis was conducted for 71 countries to confirm the findings. Another Time Series Analysis shows a strong positive correlation between financial development and growth in 13 OECD (Organisation for Economic Cooperation and Development) countries for the period of 1970-1991, (Neusser and Kugler, 1998). Furthermore, a study on 71 countries for the period of 1960-1995 has revealed and supported the positive correlation between inclusive financial system and economic growth, (Levine et al., 2000).The financial markets in most of the developing countries like India are at their infancy. Financing enterprise start-ups and restructuring is a crucial and challenging task. Micro-credit has the capacity to do so along with some more advanced and innovative financial products (Yunus, 2008). However, several studies related to the established market economies suggest that entrepreneurs are liquidity-constrained (Evans and Jovanovis, 1989; Honohan, 2004; Rajanand Zingales, 2003; Moore, 2004) Lack of finance is one of the most crucial factors, for the entrepreneurial failure of the nascent enterprises (Reynolds et al., 2000). The channel through which the business environment influences the economic development is the entry of new firms (Klapper, Laeven and Rajan, 2006). And MSME sector in India has the potential to absorb these numerous vulnerable enterprises, craving for self-empowerment. The rural India is extremely financially excluded (Basu, 2006) and this could be the one major reason for rural indebtedness and poverty. Another study indicates that entrepreneurs are more likely to reinvest their profits if they are more confident about the system of protection of property rights. They can use their property as collateral for getting easy and timely loans, the effect being stronger for smaller firms (Johnson et al, 2002; Cull and Xu, 2005). Another study was conducted (Ayyagari, Demirgue and Maksimovic, 2005), using firm-level survey data on business environment across 80 countries and the lack of finance has been identified as one of the most powerful obstacles to the growth of firms.According to a recent world-wide study ( IFCand World Bank, 2010), 45-55\% of the formal MSMEs in the emerging markets do not have access to formal institutional credit despite an urgent need of the same. The finance gap is around $65-72 \%$ of all the MSMEs (240-320 million) in the emerging market economies. Access to easy and affordable financial services can help the MSME sector to upgrade obsolete techniques of production and engage in product innovation with sound and modern technologies to be able to compete in the international markets, produce those goods that command global demand ( like China ) and integrate with the world economy to enjoy the fruits of globalization. The National Commission on Enterprises in Unorganized Sector (NCEUS) has estimated the credit gap for only the micro enterprises in India at $73 \%$ at the end of March 2012. At the beginning of the $12^{\text {th }}$ Five Year plan period the outstanding credit gap for the MSME sector is found to be $62 \%$ which is estimated to be reduced to $43 \%$ by March 2017 with assumption of minimum $20 \%$ Y $\mathrm{Y}$ credit growth in the MSME sector by all the Scheduled Commercial Banks (Ministry of MSME,GOI, 2010).The MSME sector has consistently registered higher growth in India, as compared to the overall industrial sector, in the recent years. It contributes nearly $45 \%$ of the total manufacturing sector and $40 \%$ to the export sector in India. Its contribution to GDP is $8 \%$ and it has registered a growth rate of $10.8 \%$, which is higher than the country's GDP growth rate (RBI, 2011). The huge potential of this sector is, however, facing numerous challenges in the form of sub-optimal scale of operations, technological obsolescence, increasing domestic and global competition, changes in manufacturing strategies and technology, and turbulent market scenario with grave imperfections (Ministry of MSME, 2011). In order to sustain the momentum of GDP growth over 9\% pa, it becomes imperative to build a conducive and enabling environment which can ensure local demand and consumption to give a boost to its domestic growth story.

\section{Objectives of the study/ Research gap}

This particular study attempts to explore whether the new breed of capitalism, i.e. capitalism which is inclusive and creative, (Gates, 2008), is capable of spurring entrepreneurship in the country which can give a sustained momentum to the rapid economic growth that India is poised to take-off. It is an attempt to understand and appreciate how a transparent credit system with simplification and reduced documentation for accessing finance could result in entrepreneurship development, particularly in the MSME (Micro, Small and 
MediumEnterprises) sector of the Indian economy, boosting the investment rate and building up more than envisaged momentum of growth by unleashing their under-utilised productive potentials. Mobilising the potential productivity of the youth and women entrepreneurs would enable India in "reaping the demographic dividends", (Bloom, 2008), thus, insulating its economy from current global recessionary trends. This study dwells on the significance of the inclusiveness of the financial services to inculcate inclusive capitalism and entrepreneurship within the MSME in India to ensure the growth trajectory more meaningful and sustainable in the long run. MSMEs constitute an important segment of the Indian economy (Awasthi, 2004). The nationalisation of banks and liberalisation of the financial sector has relieved this sector from stagnation and launched it on the path of self-sustaining growth. However, notwithstanding the increase in bank credit to this sector, the statistics of the fourth Census of MSE sector reveals that only $5.18 \%$ of the vast MSE sector avails institutional finance, $2.05 \%$ units avail finance from non-institutional sources and the majority of the units $92.77 \%$ had no finance, implying dependence on self-finance (YES SME, 2012). Inclusive capitalism requires long-term commitment from all the stakeholders involved in the value chain. It is the changed capitalism that delivers both private wealth and public goods. The global financial crisis of 2009 can be used as an opportunity to create new and more sustainable models of capitalism.

\section{Methodology}

Qualitative as well as quantitative techniques of research methodology have been employed to indicate the findings of the study. Secondary data sources, mainly of Reserve Bank of India have been used to establish the causal relationship between Finance and economic growth.

- Financial Deepening (percentage and amount ofcredit to MSE sector) has been taken as a parameter of inclusive finance (capitalism).

- Per capita Net NationalProduct (at factor cost) figures of Indian economy (2001-2011 at 1999-2000 price level) have been taken as parameter of economic growth.

- Total number of enterprises in the MSE sector of Indian economy has been taken as parameter of Entrepreneurship development.

- Total value of the total product of the MSME sector has been taken as a parameter of growth of MSME.

- $\mathrm{H}_{0}$ : The MSME sector development in India is not dependent on the availability of credit to this sector.

- $\mathrm{H}_{1}$ : The MSME sector development in India is dependent on the availability of credit to this sector.

Statistical software packages, SPSS (20 version), has been used to do the Regression analysis, Correlation Analysis and Goodness of Fit. It has been empirically verified that GDP growth leads to greater degree of financial inclusion, (Basu, 2005). However, this study tries to establish that the process is reinforcing, i.e. financial inclusion also leads to higher GDP (economic growth).

\section{Findings \&Implications}

In this present study, "R $\mathbf{R}^{2} \mathbf{0 . 9 5}$ ", "Appendix A.2", which is sufficiently high to establish the fact that more than $\mathbf{9 5 \%}$ of the changes (or growth) in the MSE sector has been due to availability of increasingly inclusive financial services in the country. As the F-statistic is found significant (F-Statistics=136 at 0.00 levels of significant), we reject the null hypothesis and accept the alternative hypothesis.Hence, the validity of the model gets established.

\section{A Hypothetical Modelof Entrepreneurship Development through Inclusive Capitalism:}

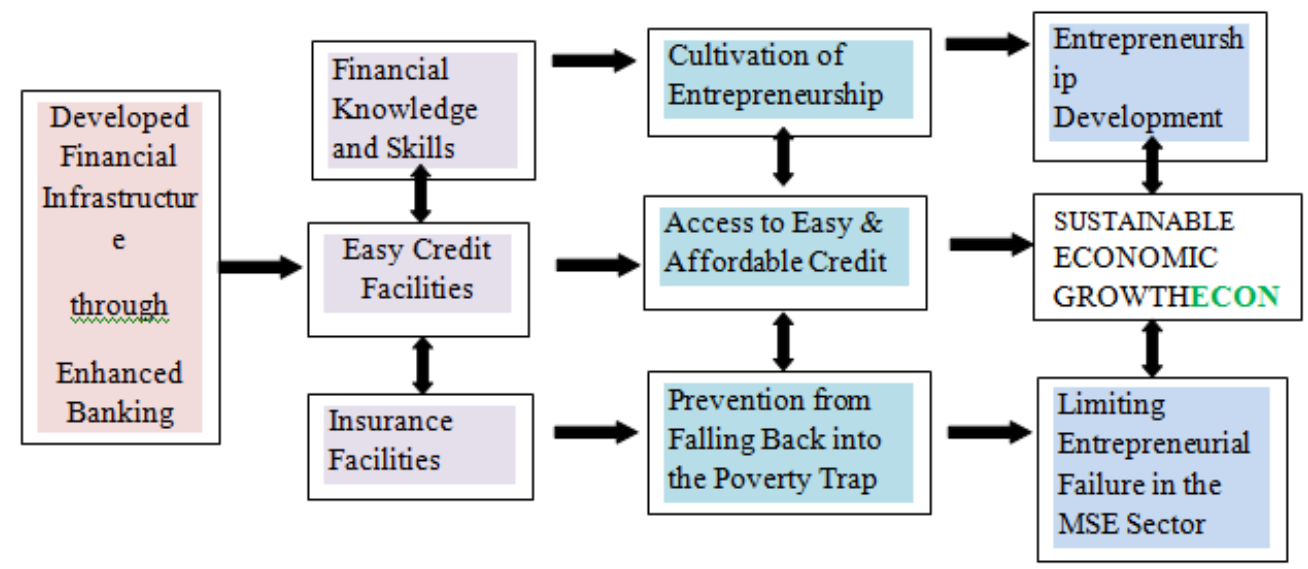

(Source: Banerji and Banerjea, 2011) 
The study deliberates the availability of innovative financial products and services development to enhance the flow and ease of access for increasing the competitiveness and enhance the success of MSME by improving their scale and scope economies. There is a lack of significant empirical evidence of a causal link between credit delivery, MSMEs and economic growth. This particular study attempts to do an impact assessment of inclusive financial services to MSME and the entrepreneurial growth within this segment of the Indian economy.

\section{Way Forward and Limitations}

The new brand of inclusive capitalism includes socio-economic sustainable businesses and consumers alike. Economic opportunities are strongly intertwined with the extent of financial access. Such an access is especially a powerful instrument for the resource-constrained MSME sector as it provides opportunities to leverage their investment scale and also insures their businesses against the cyclical shocks. The MSME sector of the country needs to be nurtured as it has the potential to converge into large industrial houses of tomorrow or even MNCs in future (Chakraborty, 2012).

The World economic growth has shown frail and subtle signs of improvement in the recent months, yet the scenario is quite grim and the prospects are still challenging. The World economic growth is likely to remain dull and insipid (falling below 3\% in 2012) and projected around 3\% only in 2013(World Economic Situation \& Prospects-WESP, 2012). The major weaknesses that continue to feed into each other and act as obstacle to robust growth are continuous deleveraging by the financial institutions, massive unemployment, fiscal austerity that has to be observed to deal withcontinuously rising crude oil prices plus rising public debt and banks' exposure to sovereign debt which is perpetuating financial sector fragility. After decelerating from $9.2 \%$ growth of Indian GDP in 2009 to $5.5 \%$ in 2011 , India needs to stimulate its investment rate phenomenally to accelerate the pace of development. This can be feasible only by increasing the competitiveness of the MSME which can be possible by creating enabling conditions and eliminating the obstinate and formidable financial constraints in doing business, especially in a developing third world country like India.

The studies to establish the causal relationship between entrepreneurship development and inclusive capitalism are scarce and offer fertile area of research. India's entrepreneurial development is at crossroads today, signalling strong potential for exponential addition to value. Although, the World Bank researchers have found positive correlation between the size of the SME sector and growth in GDP (Beck et al, 2003), but this does not necessarily prove that causation runs from SME to growth in GDP. The strategy of inclusive capitalism provides insights into responsible enterprise trends. However, a study of this nature faces numerous data-driven limitations and contentious efforts.

Appendix. A: P-P Plots generated by SPSS 20 for the study revealing linear and normal relationship among the dependent and the independent variables.

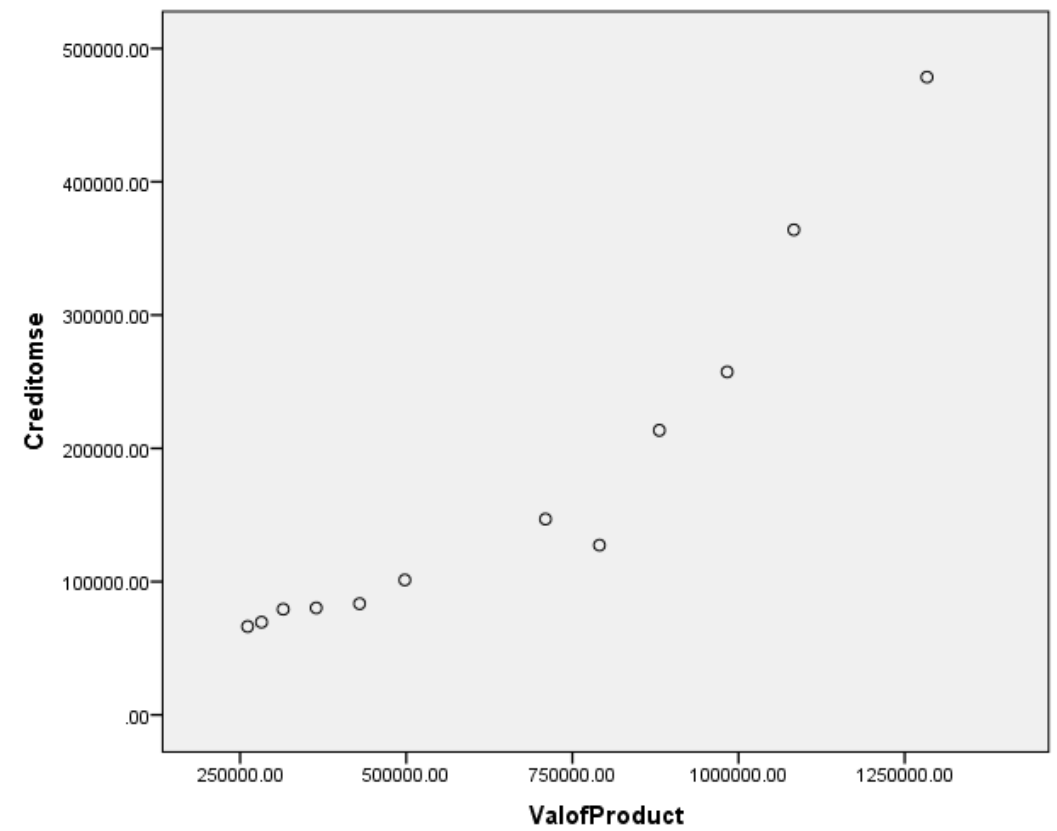

A.1: 
A.2: Output generated by SPSS 20. The Regression Analysis results shows $R^{2}=0.96$, statistically significant at 0.00 levels of significance.

\begin{tabular}{|c|c|c|c|c|c|c|c|c|c|c|}
\hline \multirow[b]{3}{*}{ Model } & \multirow[b]{3}{*}{$\mathrm{R}$} & \multirow[b]{3}{*}{ R Square } & \multirow[b]{3}{*}{$\begin{array}{l}\text { Adjusted R } \\
\text { Square }\end{array}$} & \multirow[b]{3}{*}{$\begin{array}{l}\text { Std. Error of } \\
\text { the Estimate }\end{array}$} & \multicolumn{6}{|c|}{ Model Summary } \\
\hline & & & & & \multicolumn{5}{|c|}{ Change Statistics } & \multirow[b]{2}{*}{$\begin{array}{l}\text { Durbin- } \\
\text { Watson }\end{array}$} \\
\hline & & & & & $\begin{array}{c}\text { R Square } \\
\text { Change }\end{array}$ & F Change & df1 & $\mathrm{df} 2$ & Sig. F Change & \\
\hline 1 & $.984^{\mathrm{a}}$ & .968 & .961 & 68656.77388 & .968 & 136.321 & 2 & 9 & .000 & 1.377 \\
\hline
\end{tabular}

a. Predictors: (Constant), Subsidytomse, Creditomse

b. Dependent Variable: ValofProduct

Appendix. B: Evidence of strongly positive correlation between the dependent and the independent variables.

Correlations

\begin{tabular}{|ll|r|r|r|}
\hline & & & \multicolumn{2}{|c|}{$\begin{array}{c}\text { Subsidytoms } \\
\text { ValofProduct }\end{array}$} \\
\hline Pearson Correlation & ValofProduct & 1.000 & .934 & .980 \\
& Creditomse & .934 & 1.000 & .917 \\
& Subsidytomse & .980 & .917 & 1.000 \\
\hline Sig. (1-tailed) & ValofProduct &. & .000 & .000 \\
& Creditomse & .000 &. & .000 \\
& Subsidytomse & .000 & .000 &. \\
\hline $\mathrm{N}$ & ValofProduct & 12 & 12 & 12 \\
& Creditomse & 12 & 12 & 12 \\
\hline
\end{tabular}

\section{References}

[1] Ayyagari,M., Beck,T.andDemirguc-Kunt,A. (2003),"Small and medium enterprises across the globe: A new database”. World Bank Policy Research Paper 3127.

[2] Banerji, R. and Banerjea, S. (2011), "Role of Financial inclusion in limiting Entrepreneurial Failure in Transitional countries like India: A Diagnostic Approach

[3] Basu, P. (2006), "Improving Access to Finance for India's rural poor", World Bank Policy Research Paper 3646.

[4] Bloom,E.D.,Canning.D. andSevilla J. (2003), "The Demographic Dividend, New Perspective on Economic Consequences of Population Change", Pittsburgh: Rand.

[5] Chakrabarty, K.C.(2011), "Microenterprise Development: Path to Creating MNCs of Tomorrow", RBI Publications, Mumbai.

[6] Cull, R. and Xu, L.C. (2005), "Institutions, Ownership, and Finance: The Determinant of Profit Reinvestment among Chinese Firms", Journal of Financial Economics, 77, 117-146.

[7] Evans, D. and Jovanovic, B. (1989), "An Estimated model of Entrepreneurial Choice under Liquidity Constraints", Journal of political Economy, 97, 808-827.

[8] Honohan, P. (2004), "Measuring Microfinance Access: Building on Existing Cross Country data", World Bank Publications, Washington DC.

[9] ILO (2007), “The Informal Economy: Enabling transition to formalisation", Geneva, ILO Publications.

[10] King, R. G. and Levine, R. (1993), "Finance, entrepreneurship, and growth: Theory and evidence", Journal of Monetary Economics, 32, 513-542.

[11] Klapper, L., Laeven, L. and Rajan, R. G. (2006), "Entry regulations as a barrio to Entrepreneurship", Journal of Financial Economics, 82(3), 591-692.

[12] Landes, D. (1998), "The Wealth \& Poverty of Nations: Why some are so rich and some so poor", NewYork,W.W Norton \& Company.

[13] Levin, R. (1997), "Financial Development and Economic Growth: Views and Agendas", University Of Virginia, Journal of Economic Literature, 35 (2): 688-726.

[14] Levine, R., Loayza, N. and Beck, T. (2000), "Financial intermediation and growth: Causality and causes", Journal of Monetary Economics, 46, 31-77.

[15] Mckinsey\&Company and IFC, (2010), "Two Trillion and Counting", World Bank Publications.

[16] Ministry of MSME,(2011), “Annual Report”, Government Of India Publications, Delhi

[17] Moore, K. (2004), "Do Liquidity Constraints matter for New Entrepreneurs", Washinton DC, Federal Reserve System.

[18] Neusser, K. and Kugler, M. (1998), "Manufacturing growth and Financial development: evidence from OECD countries", Review of Economics and Statistics, 80, 638-646.

[19] Odedokun, M. O. (1996), "Alternative Econometric approaches for Analyzing the role of the Financial sector in Economic growth: Time -series evidence from LDCs", Journal of development Economics, 50(1), 119-146.

[20] Prahalad,C.K. and Krishnan,M.S. (2008), "The New Age of Innovation”, McGraw-Hill.

[21] Rajan,R., and Zingales, L. (2003), "The Great reversals: The politics of Financial Development in the twentieth century", Journal of Financial Economics, 69, 5-50.

[22] RBI,(2011), “Annual Reports", Mumbai, RBI Publications

[23] Reynolds,P.D., Storey,D. and Westhead, P. (1994), "Regional Variations in New Firm Formation”, Regional Studies 28: 44-46.

[24] Schumpeter,J.A. (1949), “The Theory of Economic Development”, Cambridge, MA, Harvard University Press. 
[25] Shane, S. and Venkatraman, S. (2000), "The Promise of Entrepreneurship as a Field of Research", Academy Of Management Review, 25(1): 217-226.

[26] Soto, De (2003), "The Mystery of Capital: Why Capitalism Triumphs in the West and Fails Everywhere Else", New York, Basic Book, 276.

[27] Studwell, J. (2002), “The China Dream”, New York, Atlantic Monthly Press, 192.

[28] Venkatraman, S. (2004), "Regional transformation through technological entrepreneurship", Journal of Business Venturing, 19, 1, 153-167.

[29] YESME, (2012), “Role of the Government in SME Financing”, Yes Bank Publications

[30] Yunus, M. (2008), Creating World without Poverty: Social Business and Future Capitalism, Public Affairs, Bangladesh. 